\title{
0 riso grego na cena americana
}

\section{Donato Loscalzo}

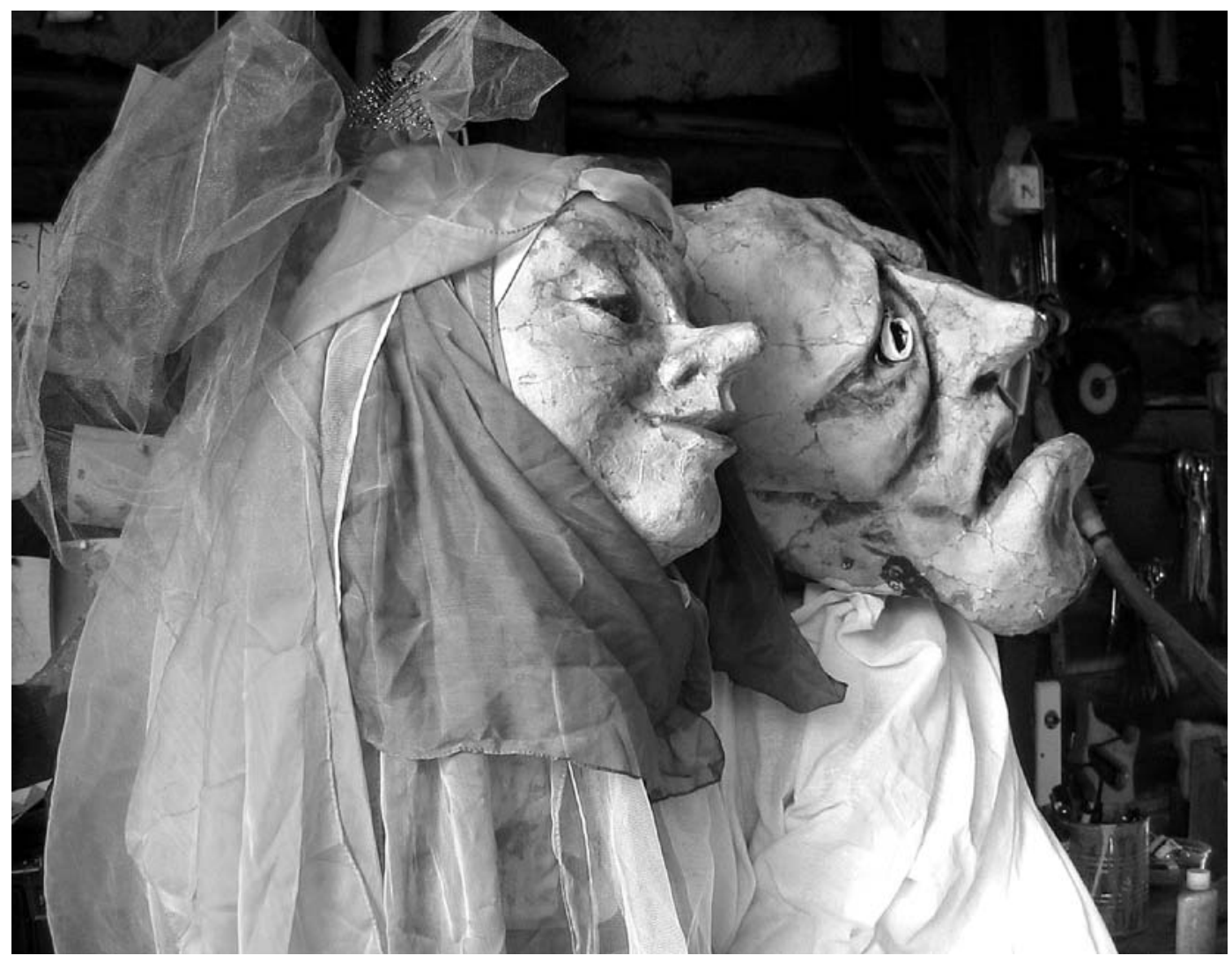

As livrarias de Nova lorque - e não só as especializadas em teatro - têm, entre outras secções, duas particularmente ricas: as dedicadas a Shakespeare e a Aristófanes. Os dois dramaturgos contam com numerosas edições, ensaios, reconstruções e reedições das suas obras. Se para o primeiro é fácil entender a razão de um êxito tão grande, em relação ao segundo há a questão peculiar de um autor cómico ateniense do século V-IV a.C. despertar ainda hoje o interesse de muitos estudiosos e autores de teatro. Tratase de um poeta de montagem dificil, porque as suas peças estão cheias de referências à realidade específica da cidade de Atenas dessa época. Falam de personagens que existiram realmente - políticos e intelectuais, desonestos, malfeitores e corruptos - de quem muitas vezes se ignora a identidade. Encaram problemáticas historicamente determinadas e ligadas à vida ateniense, que aos olhos do espectador moderno podem parecer incompreensíveis. E justamente por estarem datadas, podem ser mais interessantes para os estudiosos de história e literatura grega do que para o público e os dramaturgos contemporâneos em geral. Contudo, o certo é que Aristófanes regressou em força, em contextos e lugares longínquos.
Apesar destas - e de outras - limitações, Aristófanes é ainda hoje um autor amado e repetidamente levado à cena nos Estados Unidos. Mesmo estando distante no tempo e tendo referentes obscuros, reapareceu na cena americana destes últimos anos, inspirando espectáculos muito estimulantes e apreciados pelo público. E isto não obstante ser tarefa complexa evocar hoje em palco as fórmulas cómicas que apaixonavam e divertiam o público há 2500 anos. Sabemos que, enquanto a tragédia consegue falar ao público de todos os tempos, o cómico, a sátira, a invectiva estão ligados à actualidade e são por isso irrepetíveis. E é verdade que na comédia de Aristófanes o quotidiano está presente em cada cena, cada situação cómica, cada sequência.

A Mettawee River Theatre Company apresentou, entre Julho e Setembro de 2007, em itinerância em Nova lorque e na periferia, A paz de Aristófanes, ou melhor, uma adaptação muito original desta comédia. Redigida em 421 a.C., a peça conta a história de um camponês, Trigeu, que decide subir ao Olimpo para pedir a Zeus a devolução da Paz aos homens, visto que a longa guerra contra Esparta estava a arruinar inexoravelmente a sua cidade. Uma vez 
chegado ao cimo do monte, ele descobre que os deuses se foram embora, deixando a sua residência habitual por estarem desgostosos com a guerra interminável. Quem tinha ficado no antigo lugar divino era Pólemos, deus da guerra, que mantinha cativa e escondida numa caverna Irene, a paz. Trigeu consegue libertá-la com a ajuda dos outros trabalhadores rurais, os mais atingidos pelo desastre. A companhia que mostrou esta releitura da Paz reproduz parcialmente a atmosfera festiva das representações cómicas atenienses da altura, evocando também o seu espírito folclórico: máscaras gigantes, música ao vivo e danças.

Nestes últimos dois anos Aristófanes inspirou ainda espectáculos de dança, como é o caso de Aristophanes in Birdonia, pela David Gordon's Dance-Theater, baseado n' As aves. Esta peça é de 414 a.C. e fala de dois velhos atenienses, cansados de uma vida citadina dominada por lutas e confusões várias, que decidem perguntar à poupa onde é que se pode viver em paz. Resolvem então construir uma cidade nas nuvens, a meio caminho entre homens e deuses, ajudados pelas aves. Estas, que inicialmente desconfiavam dos dois homens, resolvem apoiar o seu projecto, a fim de reivindicarem junto de Zeus o seu antigo domínio sobre o mundo, posteriormente usurpado pelos deuses. Neste bailado a cidade americana assume as caracteristicas da cidade de Atenas de finais do século $\mathrm{V}$ e os dois protagonistas são assimilados a Bucha e Estica, na sua ingénua procura de justiça. Uma procura demasiado exigente, titânica mesmo, para dois simples mortais.

Mark Adamo, compositor de successo, apresentou em 2005 na Houston Grand Opera e em Março de 2006 na City Opera de Nova lorque Lysistrata, or the Nude Goddess, uma ópera que suscitou alguma surpresa pelo seu tema inusual. Inspirada na peça Lisistrata, fala na greve de sexo decretada e assumida pelas mulheres de Atenas e Esparta, chefiadas por Lisistrata. Querem assim convencer os seus maridos a acabar com a guerra longa e dispendiosa que estava a enfraquecer os recursos humanos e financeiros das duas cidades. Adamo compôs o libreto em 2000, antes da guerra no Iraque e do ataque às torres gémeas, mas evidentemente o clima de falência de algumas políticas democráticas e a crise que percorria o país eram vividos com um sentido de urgência. A alusão à guerra concreta era evidente e mereceu louvores a ironia corajosa com que o compositor soube enfrentar esse tema, de abordagem dificil num quadro artístico, servindo-se do tema universal da guerra entre os sexos para o transpor para o conflito civil.

No Verão de 2005 uma outra versão da Lisístrata foi levada à cena em Nova lorque por Jason Tyne. Neste caso o referente da guerra no Iraque era explícito e óbvio,

homem de nome Tereu

que entretanto foi

transformado em pássaro. as mulheres da sua greve, tinha o nome de George W. Bush.
A lista dos espectáculos baseados em comédias de Aristófanes seria mais longa, mas o aspecto mais interessante reside em compreender as razões das revisitações contemporâneas de um autor cómico que falava com o seu público de problemas e temas próprios do seu tempo. Um dos motivos, talvez, deve ser procurado na atitude que Aristófanes mostra em relação à política, bem como ao sentido que quis dar a uma comicidade que parece ter mais propriamente, como vimos, os traços da sátira política. As suas censuras e reprimendas são dirigidas sobretudo às disfunções da democracia ateniense e ao problema candente da guerra entre Atenas e Esparta. Neste âmbito é preciso procurar as afinidades e as problemáticas que tornaram possivel a reevocação do riso cómico grego nos teatros americanos.

$\mathrm{Na}$ sua aparente leitura superficial da crise contemporânea, Aristófanes capta a justeza das razões mais profundas. A estrutura que regia a democracia ateniense atingira custos elevadissimos e alguns intelectuais começavam a perceber a ineficácia das escolhas políticas anteriores. Para conseguir sobreviver, a democracia precisava de conquistar novos territórios, novos mercados. Alguns políticos encontravam na guerra uma possivel solução para a crise, mas para ter o consentimento das massas reunidas nas assembleias, a guerra tinha que ser defendida como missão democrática: a pretexto de divulgar o seu excelente sistema democrático, Atenas procurava, na verdade, terras para conquistar e tesouros para importar, a fim de conseguir manter um sistema político que já se tornara insustentável. A guerra devia ser explicada como defesa necessária e inevitável contra os inimigos da democracia. Por trás desta fachada estava uma simples guerra imperialista, que levava não à reestruturação do estado, mas antes à sua inexorável e progressiva desagregação. As vítimas da guerra eram maioritariamente das classes menos abastadas e mais fracas, os pobres, as mulheres, os jovens, enquanto só uma classe, restringida aos produtores de armas, beneficiava dela. Esta é, por exemplo, a mensagem veiculada por Acarnenses.

É certo que o género cómico incide sobre os aspectos banais, corriqueiros e ordinários do quotidiano, tornando assim protagonistas da cena sujeitos que, de outra forma, não teriam voz. Mas por trás desta escolha não há somente razões de homenagem ao género. Aristófanes quer representar o lado obscuro e escondido da vida da cidade, tentando criticar os problemas sociais que ameaçavam o normal funcionamento das instituições. Ou seja, trata-se de uma comédia empenhada e de denúncia.

0 objectivo do dramaturgo é pedagógico, pois quer ensinar a perceber como funcionam as relações entre os cidadãos, como é que o indivíduo se deve relacionar com o ambiente exterior e o que é que pode exigir da pólis. Como o próprio autor admite, o poeta deve "ensinar muitas 


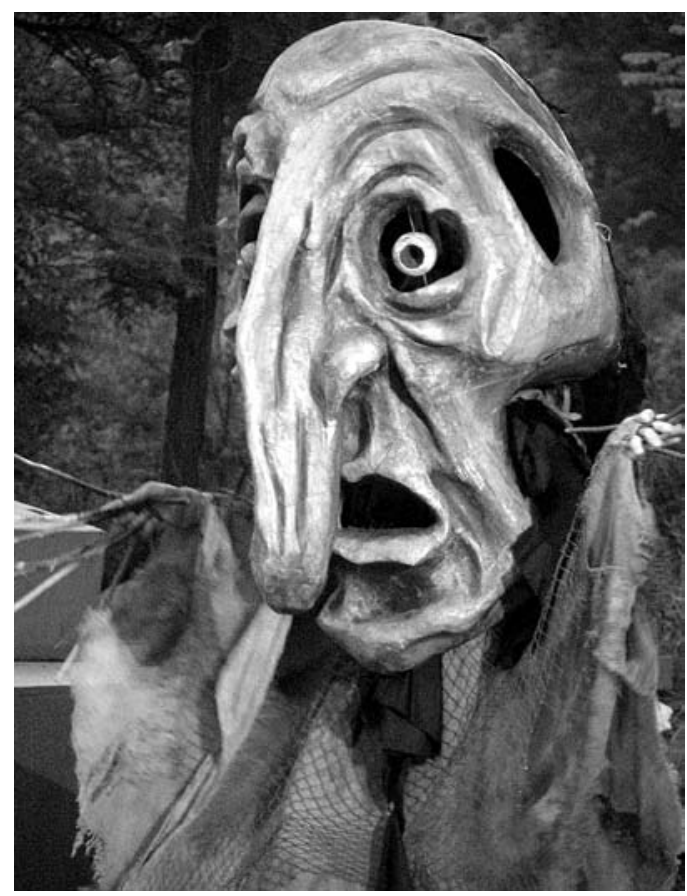

coisas úteis para que os espectadores sejam felizes" (Acarnenses 656), pondo de maneira decidida e declarada, como fundamento da sua poética, o tema da felicidade. A obra dele, portanto, tem repercussões de âmbito moral e reporta-se à vida de todos os dias, onde se pode concretizar o modelo de vida feliz. Trata-se de definir o que é a felicidade, mas em geral ela parece ser uma consequência da atitude de denúncia e clarificação que deve ser praticada pelo autor da comédia. Aristófanes é o primeiro dramaturgo que atribui ao poeta uma tarefa tão elevada e de certa forma insólita. Aos olhos dele a comédia é uma obra que deve não apenas garantir o riso imediato e efémero na cena, mas também - e sobretudo - abrir caminho para se atingir o ideal superior da felicidade. Em épocas anteriores, divertir e entreter eram os objectivos imediatos do poeta. Aristófanes, pelo contrário, quer ir mais longe. Para que o espectador possa ser feliz é necessário que reelabore as mensagens mediadas pela peça: o público é chamado a cumprir uma tarefa inusual, porque deve reflectir, meditar, racionalizar os conteúdos veiculados pela comédia. Deve, afinal, interagir com o

poeta, a partir do momento em que compreende a realidade e acordar do torpor da passividade, considerada o maior dos males da vida democrática. Uma das acusações recorrentes, de resto, é mesmo a da inércia em que vive adormecido o cidadão ateniense. E este sono é muito perigoso, porque leva os politicos sem escrúpulos a cuidar dos seus interesses particulares, sabendo que a sua conduta é aceite passivamente.

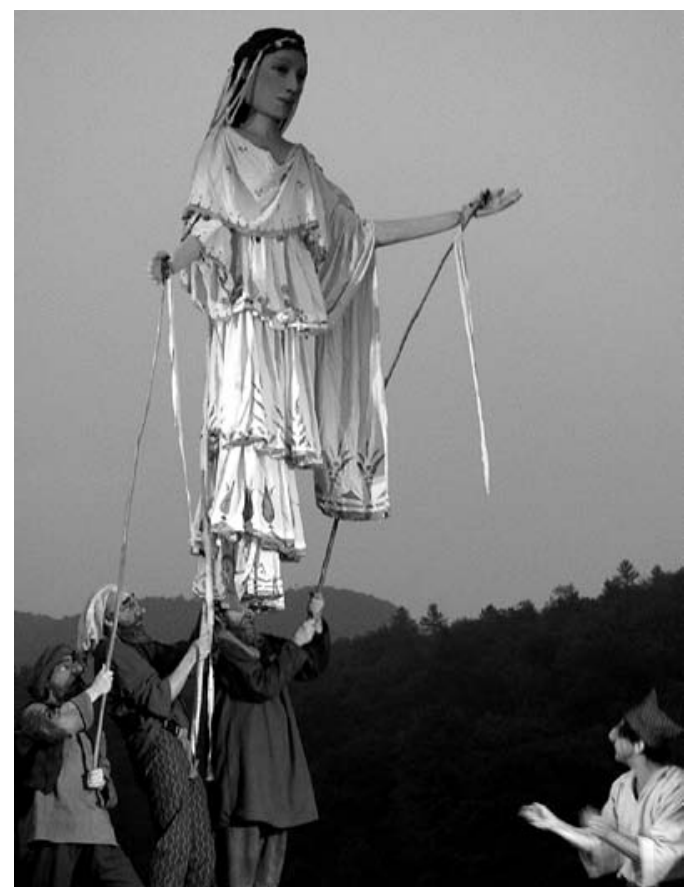

Comparado com os outros géneros teatrais, a comédia foi no mundo antigo o género mais popular e bem sucedido. Por essa razão o comediógrafo podia influenciar os ouvintes, mas, além disso, cabia-lhe também ser portavoz da contestação e da discordância. Unicamente revendo, como num espelho, a vida de todos os dias, era possível fornecer ao cidadão o instrumento crítico que permitisse uma releitura da sua vivência. A mensagem de Aristófanes não ia no sentido de acusar o "sistema", ou melhor, não era só a isso que se dirigia a sua comicidade. 0 seu riso atingia as consciências dos espectadores de forma original, na medida em que parecia provar como é que cada um estava envolvido na crise de Atenas e como, por essa razão, não deixava de ser responsável pela sua própria queda. A intenção era despertar as consciências que tinham dado a sua procuração aos poderes fortes, e entregue a gestão do estado democrático aos arrogantes. Cada um tinha-se retirado para a sua vida privada, pensando assim conseguir sobreviver à crise, cultivando o seu interesse pessoal, necessariamente limitado. Entretanto, a desagregação alastrava e, lentamente, contagiava a vida de todos, devendo a miséria ser um sinal de alarme imediato. Todavia, os cidadãos enquanto indivíduos adiavam toda e qualquer tomada de posição e de consciência.

Não surpreende que Aristófanes seja considerado actual. De facto, é até profético.

Tradução de Sebastiana Fadda
$<>$

Peace (A paz)

de Aristófanes enc. Ralph Lee, The Mettawee River Theatre Company, 2007 (< Ganância; $>$ Paz), cortesia de The Mettawee River Theatre Company. 